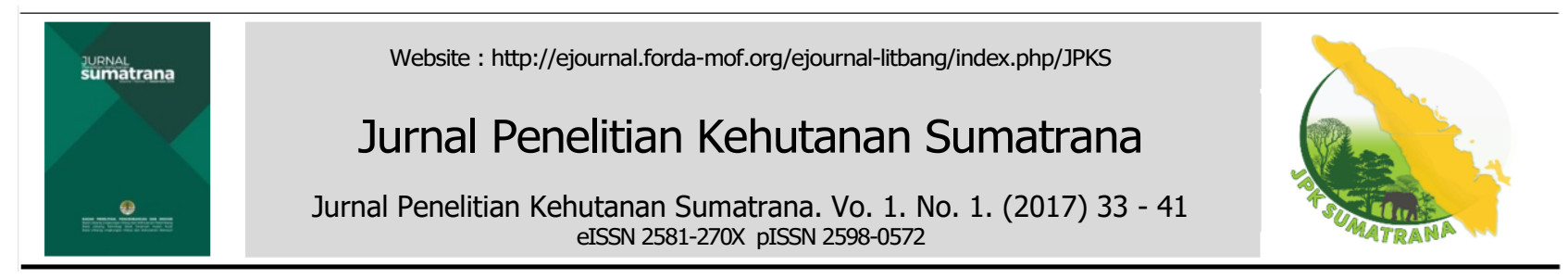

\title{
Serapan Karbon Hutan Tanaman Krasikarpa Pada Lahan Basah Di Kabupatan Ogan Komering Ilir Sumatera Selatan
}

\section{(Carbon Sequestration of Krasikarpa Plantation on Wetlands in Ogan Komering Ilir District, South Sumatera)}

\author{
Hengki Siahaan ${ }^{1 *}$, Agus Sumadi ${ }^{1}$ \\ ${ }^{1}$ Balai Penelitian Pengembangan Lingkungan Hidup dan Kehutanan Palembang \\ Jl. Kol. H. Burlian KM 6,5 Palembang \\ *Email: hengki_siahaan@yahoo.co.id
}

Article History:

Received 10 February 2017; Received in revised form 3 Agust 2017

Accepted 10 Agust 2017; Available online since 30 Sept 2017

\begin{abstract}
ABSTRAK
Hutan tanaman industri yang dibangun pada lahan terdegradasi seperti semak belukar dan padang rumput dapat meningkatkan serapan karbon pada lahan tersebut. Penelitian ini bertujuan untuk menilai serapan karbon hutan tanaman krasikarpa (Acacia crassicarpa) yang dibangun pada lahan rawa terdegradasi di Kabupaten Ogan Komering Ilir (OKI), Sumatera Selatan. Penelitian dilakukan dengan menganalisa data dari 433 petak ukur permanen yang dibangun pada berbagai tipe lahan basah, diantaranya tipe lahan endapan liat (marine clay), gambut dangkal (peat VI) dan gambut dalam (peat VII). Petak-petak pengukuran ini diukur dari tahun 2005 sampai tahun 2014. Hasil penelitian menunjukkan bahwa model serapan karbon berbeda pada masing-masing tipe lahan basah, yaitu $Y=$ $34,82 /(1+77,71$ exp $(-1,44 X))$ pada tipe lahan endapan liat, $Y=28,05 /(1+17,64 \exp (-0,96 \mathrm{X}))$ dan $\mathrm{Y}$ $=25,52 /(1+40,89 \exp (-1,47 X))$ pada tipe lahan gambut dangkal dan gambut dalam. Berdasarkan model tersebut, serapan karbon maksimum berbeda pada tiap tipe lahan, yaitu sebesar 34,82 ton $\mathrm{C} / \mathrm{ha}$ pada lahan endapan liat; 28,05 ton C/ha pada gambut dangkal (peat VI) dan 25,52 ton C/ha pada lahan gambut dalam (peat VII). Riap serapan rata-rata maksimum pada lahan endapan liat dan gambut dangkal terjadi pada umur 4,25 tahun sebesar 7,0 dan 5,08 ton $\mathrm{C} /$ ha/tahun, tetapi pada tipe lahan gambut dalam terjadi lebih dulu yaitu pada umur 3,75 tahun sebesar 5,89 ton C/ha/tahun.
\end{abstract}

Kata kunci: Acacia crassisarpa, serapan karbon, hutan gambut, lahan rawa terdegradasi, petak ukur permanen

\begin{abstract}
The industrial forest plantation developed on degraded wetland such as shrub and grassland areas could improved the carbon sequestration in the lanscapes. This research was aimed to assses the carbon sequestration of Krasikarpa (Acacia crassicarpa A. Cunn ex Benth.) plantation developed on various types of degraded wetland in Ogan Komering Ilir (OKI) district, South Sumatera. The research was conducted by analyzing data from 433 permanent sample plots that constructed on various wetland types consist of marine clay, shallow peat (peat VI), and deep peat (peat VII). The plots have been measured from 2005 to 2014. The result showed that carbon sequestration models are significantly different based on the wetland types, i.e $Y=34,82 /(1+77,71 \exp (-1,44 X))$ on marine clay, $Y=28,05 /(1+17,64 \exp$ ($0,96 X))$ and $Y=25,52 /(1+40,89 \exp (-1,47 X))$ on shallow peat and deep peatland respectively. Based on the model, the maximum carbon sequestration was different on each wetland type, amounted at 34,82 ton C/ha on marine clay; 28,05 ton C/ha on shallow peat (peat VI) and 25,52 ton C/ha on deep peat (peat VII). The maximum mean annual of carbon sequestration on marine clay and peat VI occured in the age of 4,25 year, amounting of 7,0 and 5,08 ton C/ha/year but on peat VII occured earlier i.e at the age of three year amounted at 5,89 ton C/ha/year.
\end{abstract}

Keywords: Acacia crassisarpa, carbon sequestration, peat forest, degraded wetland, and permanent sample plots 


\section{PENDAHULUAN}

Sektor penggunaan lahan yang meliputi pertanian, kehutanan, dan penggunaan lahan lainnya atau AFOLU (agriculture, forestry and other land use) merupakan sumber emisi kedua terbesar setelah sektor energi. Menurut laporan IPPC (tahun 2014), sektor ini menyumbang emisi 32\% dari emisi global sebesar 49,5 Gt $\mathrm{CO}_{2}$ eq pada tahun 2010. Proporsi ini diperkirakan akan lebih besar di negara-negara berkembang (Victor et al., 2014). Di Indonesia, sektor penggunaan lahan menyumbang $65 \%$ dari total emisi nasional (Krisnawati, 2010). Penurunan laju deforestasi dan pembangunan hutan tanaman, baik pada lahan kering (terestrial) maupun lahan basah (wetland) merupakan upaya penting untuk mengurangi emisi dan konsentrasi gas rumah kaca (GRK) di atmosfir (Devi et al., 2013; Marchio, Savarese, Bovard, \& Mitsch, 2016; Wibowo, 2010).

Ekosistem lahan basah mempunyai peran penting sebagai penyerap dan penyimpan karbon, baik dari atmosfir melalui proses fotosintesis yang disimpan dalam bentuk biomassa pohon, maupun melalui akumulasi sedimentasi dari bagian hulu daerah aliran sungai (Mitsch et al., 2013; Rochmayanto, Darusman, \& Rusolono, 2013; Sang, Lamb, Bonner, \& Schmidt, 2013). Pada sisi lain, lahan basah terutama lahan gambut dapat menjadi sumber emisi yang besar jika tidak dikelola dengan baik. Di Sumatera Selatan, degradasi lahan rawa dan gambut merupakan sumber emisi yang cukup signifikan (Krisnawati, 2010). Emisi akibat perubahan lahan dan degradasi gambut di kawasan ini mencapai 50,8 juta ton $\mathrm{CO}_{2} \mathrm{eq} /$ tahun (Krisnawati, 2010). Emisi ini berasal dari perubahan penggunaan lahan dari tutupan hutan menjadi non hutan, drainase lahan gambut dan kebakaran hutan dan lahan.

Kebakaran hutan dan lahan basah secara berulang, pada musim kemarau di Sumatera Selatan menyisakan ekosistem lahan basah terdegradasi berupa semak belukar dan padang rumput. Dari 1,28 juta ha lahan gambut di Sumatera Selatan, 0,61 juta ha merupakan semak belukar dan sekitar 0,17 juta hektar berupa rumput- rumputan (Agus, 2013). Lahan-lahan terdegradasi tersebut akan semakin meluas jika lahan basah yang tersisa dibiarkan tanpa pengelolaan yang baik. Salah satu upaya pengelolaan lahan gambut adalah melalui pembangunan hutan tanaman.

Pengelolaan lahan rawa dan gambut dalam bentuk hutan tanaman diharapkan dapat mencegah terjadinya kebakaran, terutama pada pengelolaan areal konsesi. Selain itu, pembangunan hutan tanaman diharapkan dapat meningkatkan cadangan karbon melalui penyerapan $\mathrm{CO}_{2}$ dari atmosfir dan menyimpannya dalam bentuk biomassa tanaman. Jenis tanaman krasikarpa (Acacia crassicarpa A. Cunn. Ex Benth.) merupakan salah satu jenis yang adaptif pada kondisi anaerob dan mempunyai pertumbuhan yang cepat (fast growing) sehingga potensial ditanam pada lahan basah terdegradasi. Selain itu jenis ini merupakan penghasil kayu serat sebagai sumber bahan baku industri pulp dan kertas. Pembangunan hutan tanaman Acacia crassicarpa telah dilakukan di Kabupaten Ogan Komering Ilir (OKI) sejak tahun 2003 oleh PT. SBA Wood Industries. Penanaman krasikarpa dilakukan pada tipe lahan yang terdapat pada lahan basah di Kabupaten OKI yaitu tipe lahan endapan liat, gambut dangkal (kedalaman gambut $<1$ meter), dan gambut dalam (kedalaman $>1$ meter) yang masing-masing digolongkan ke dalam kelas kualitas lahan IV, VI, dan VII. Namun demikian, informasi pertumbuhan dan seberapa besar perannya sebagai penyerap karbon pada hutan tanaman dengan luas areal konsesi sebesar 142.355 ha belum banyak diketahui. Sumadi, Rahmat, \& Rahman (2013) telah melakukan penelitian awal serapan karbon dan menyusun model allometrik serapan karbon krasikarpa, namun model serapan karbon yang disusun hanya menggunakan plot yang sangat terbatas dan belum mewakili seluruh tipe lahan yang terdapat pada lahan basah. Penelitian ini bertujuan untuk melakukan penilaian serapan karbon pada berbagai tipe lahan basah pengembangan hutan tanaman krasikarpa pada areal konsesi PT. SBA Wood Industri di Kabupaten OKI, Sumatera Selatan. 


\section{METODE PENELITIAN}

\section{A. Waktu dan Lokasi Penelitian}

Penelitian dilakukan pada areal konsesi perusahaan PT. SBA Wood Industries di Kabupaten OKI, Sumatera Selatan. Data yang digunakan adalah data hasil pengukuran Petak Ukur Permanen (PUP) perusahaan yang diukur selama periode tahun 2005-2014. PUP tersebut dibangun pada tiga tipe lahan yaitu tipe lahan endapan liat (marine clay), gambut dangkal (peat VI), dan gambut dalam (peat VII) yang masingmasing tergolong ke dalam kelas kualitas lahan IV, VI, dan VII. PUP dibangun secara proporsional sesuai dengan luas penanaman pada masing-masing tipe lahan dan diupayakan mewakili semua kelas umur. Namun demikian, banyaknya pohon yang tumbang pada umur tua (mendekati umur 6 tahun), jumlah PUP pada kelas umur 5-6 tahun sangat terbatas. Sebaran data PUP pada masing-masing tipe lahan berdasarkan kelas umur tanaman disajikan pada Tabel 1.

Tabel 1. Sebaran data petak ukur permanen PUP krasikarpa (Acacia crassicarpa) di areal konsesi PT. SBA Wood Industries berdasarkan tipe lahan dan kelas umur tanaman

Table 1. Permanent sample plot (PSP) data distribution of krasikarpa (Acacia crassicarpa) on PT. SBA Wood Industries concession based on land types and plant age classes

\begin{tabular}{|c|c|c|c|c|}
\hline \multirow{2}{*}{$\begin{array}{l}\text { Kelas umur/ } \\
\text { age class }\end{array}$} & \multicolumn{3}{|c|}{ Tipe lahan/land types } & \multirow{2}{*}{$\begin{array}{l}\text { Jumlah/ } \\
\text { Sum }\end{array}$} \\
\hline & $\begin{array}{c}\text { Endapan liat/ } \\
\text { Marine clay }\end{array}$ & $\begin{array}{c}\text { Gambut dangkal/ } \\
\text { Shallow peat }\end{array}$ & $\begin{array}{c}\text { Gambut dalam/ } \\
\text { Deep peat }\end{array}$ & \\
\hline $1,0-1,9$ & 64 & 21 & 128 & 213 \\
\hline $2,0-2,9$ & 32 & 21 & 72 & 125 \\
\hline $3,0-3,9$ & 13 & 8 & 34 & 55 \\
\hline $4,0-4,9$ & 1 & 5 & 17 & 23 \\
\hline $5,0-6,0$ & 1 & 3 & 13 & 17 \\
\hline Jumlah/sum & 111 & 58 & 264 & 433 \\
\hline
\end{tabular}

\section{B. Metode}

\section{Perhitungan cadangan karbon}

Kandungan karbon dalam setiap pohon dihitung berdasarkan persamaan allometrik untuk pohon krasikarpa (Sumadi et al., 2013) dengan persamaan sebagai berikut:

$$
C=0,0361 * D^{2,26858}
$$

Keterangan:

$\mathrm{C}=$ kandungan karbon/carbon content (ton $\mathrm{C} /$ pohon $) /($ ton $\mathrm{C} /$ tree $)$

$\mathrm{D}=$ diameter setinggi dada/diameter at breast height $(\mathrm{cm} / \mathrm{cm})$

\section{Penyusunan model serapan karbon}

Model serapan karbon disusun dengan analisis regresi non linear menggunakan program Curve expert versi 1.3. Model yang digunakan adalah model logistik sebagaimana digunakan oleh (Wahyudi \& Pamoengkas, 2013) dengan persamaan sebagai berikut:

$$
Y=a /(1+\beta \exp (\mathbf{y} \mathbf{t}))
$$

Keterangan:

$\mathrm{Y}=$ serapan karbon/carbon sequestration (ton/ha)

$\mathrm{T}=$ umur tegakan/stand age (tahun/year)

$\beta, a, \mathbf{v}=$ koefisien/coefficient

\section{Riap serapan karbon}

Riap serapan karbon yang dihitung adalah riap rata-rata tahunan (mean annual increment-MAI) dan riap tahun berjalan (current annual increment-CAI), masingmasing dengan persamaan sebagai berikut:

$$
\begin{aligned}
& \text { MAI }=Y_{t} / t \\
& \text { CAI }=Y_{t}-Y_{t-1}
\end{aligned}
$$

Keterangan:

MAI = riap rata-rata tahunan serapan karbon/mean annual increment of carbon sequestration 


$\begin{aligned} \mathrm{CAI}= & \text { riap tahun berjalan serapan } \\ & \text { karbon/current annual increment of } \\ & \text { carbon sequestration } \\ \mathrm{Yt}= & \text { cadangan karbon pada umur } \mathrm{t} \\ & \text { tahun/carbon stock on } t \text { years old } \\ \mathrm{Yt}-1= & \text { cadangan karbon pada umur } \mathrm{t}-1 \\ & \text { tahun/carbon stock on } t-1 \text { years old } \\ \mathrm{T}= & \text { umur tegakan/stand age }\end{aligned}$

III. HASIL DAN PEMBAHASAN

\section{A. Hasil}

\section{Model Serapan Karbon}

Hasil analisis regresi hubungan umur (X) tanaman krasikarpa dengan serapan karbon dalam ton/hektar ( $\mathrm{Y}$ ) pada masingmasing tipe lahan basah pada HTI SBA Wood Industries disajikan pada Tabel 2. Grafik perkembangan serapan karbon pada setiap tipe lahan berdasarkan persamaan tersebut disajikan pada Gambar 1.

Tabel 2. Persamaan serapan karbon krasikarpa pada berbagai tipe lahan basah di Kabupaten OKI Sumatera Selatan

Table 2. Carbon sequestration equation of krasikarpa on various land types in OKI District, South Sumatera

\begin{tabular}{lcc}
\hline \multicolumn{1}{c}{ Tipe lahan/land type } & $\begin{array}{c}\text { Persamaan serapan karbon/ } \\
\text { Carbon sequestration equation }\end{array}$ & $\mathrm{R}^{2}(\%)$ \\
\hline Endapan liat (Marine clay) & $\mathrm{Y}=34,82 /(1+77,71 \exp (-1,44 \mathrm{X}))$ & 86,48 \\
Gambut dangkal (peat VI) & $\mathrm{Y}=28,05 /(1+17,64 \exp (-0,96 \mathrm{X}))$ & 83,14 \\
Gambut dalam (peat VII) & $\mathrm{Y}=25,52 /(1+40,89 \exp (-1,47 \mathrm{X}))$ & 83,14 \\
\hline
\end{tabular}

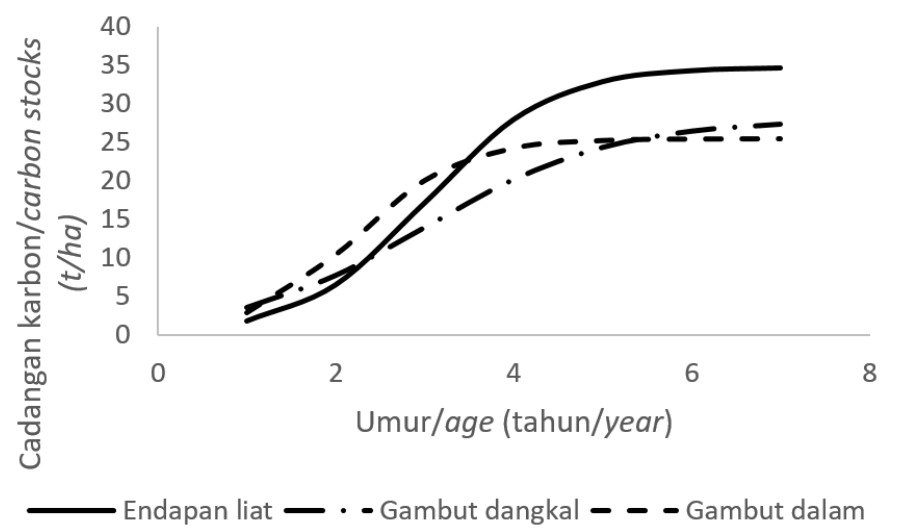

Gambar 1. Cadangan karbon tegakan krasikarpa pada tipe lahan endapan liat (marine clay), gambut dangkal dan gambut dalam di Kabupaten OKI, Sumatera Selatan

Figure 1. Carbon stock of krasikarpa stand on marine clay, shallow peat, and deep peat land in OKI District, South Sumatera

Serapan karbon pada berbagai tipe lahan basah di HTI SBA Wood Industries dapat digambarkan secara baik dengan model logistik ( $R^{2}$ berkisar antara 83,14\% $86,48 \%$ ). Model serapan karbon pada semua tipe lahan menunjukkan akumulasi karbon yang lambat pada awal pertumbuhan, kemudian meningkat pada tahap berikutnya, dan menurun pada tahap akhir (Gambar 1). Perbedaan parameter dalam model (Tabel 2) menunjukkan perbedaan potensi dan kemampuan masing-masing tipe lahan dalam menyerap karbon. Potensi serapan karbon terbesar terdapat pada tipe lahan endapan liat sebesar 34,82 ton/ha, selanjutnya pada gambut dangkal dan gambut dalam masing-masing sebesar 28,05 ton/ha dan 25,52 ton/ha yang dicapai pada umur 6 tahun.

\section{Riap Serapan karbon}

Riap serapan karbon menggambarkan besarnya karbon yang diserap tanaman setiap periode waktu tertentu. Riap serapan 
karbon dibedakan menjadi riap rata-rata tahunan (mean annual increment) dan riap pada tahun berjalan (current annual increment). Gambar 2 dan Gambar 3 menggambarkan perbandingan besarnya riap serapan karbon (per tahun) pada tiga tipe lahan pengembangan hutan tanaman krasikarpa di lahan basah di Kabupaten OKI, Sumatera Selatan. Serapan rata-rata karbon krasikarpa pada Gambar 2 menunjukkan bahwa sejalan dengan perkembangan umur tanaman, rata-rata serapan karbon terbesar terdapat pada tipe lahan endapan liat, diikuti oleh tipe lahan gambut dangkal (peat VI), dan yang paling rendah terdapat pada tipe lahan gambut dalam (peat VII). Kurva hubungan umur dan MAI serapan karbon pada Gambar 2 juga menunjukkan pola yang berbeda, yang berarti bahwa besarnya MAI maksimum dan waktu pencapaiannya berbeda pada masing-masing tipe lahan. MAI serapan karbon maksimum terbesar terdapat pada tipe lahan endapan liat yang dicapai pada umur 4,25 tahun yaitu sebesar 7,0 ton/ha/tahun, berikutnya pada gambut dangkal sebesar 5,08 ton/ha/tahun yang dicapai pada umur yang sama. MAI serapan karbon maksimum pada tipe lahan gambut dalam tercapai lebih awal, yaitu pada umur
3,5 tahun sebesar 5,89 ton/ha/tahun. Walaupun MAI serapan karbon maksimum pada tipe lahan gambut dalam lebih besar dibanding gambut dangkal, penurunan MAI yang drastis pada tipe lahan gambut dalam mengakibatkan cadangan karbon pada akhir daur (umur 6 tahun) pada tipe lahan tersebut lebih rendah dibanding tipe lahan gambut dangkal.

Riap serapan karbon tahun berjalan (CAI) menyatakan jumlah serapan karbon pada umur tertentu. Kurva CAI serapan karbon krasikarpa menunjukkan pola yang berbeda pada setiap tipe lahan. Pada tipe lahan gambut dalam, CAI maksimum terjadi lebih awal dibanding dua tipe lahan lainnya, yaitu pada umur 2,75 tahun sebesar 9,30 ton/ha/tahun. Pada tipe lahan endapan liat dan gambut dangkal CAI maksimum terjadi pada umur 3,5 tahun, masing-masing sebesar 11,7 ton/ha/tahun dan 6,5 ton/ha/tahun (Gambar 3). Pada Gambar 3 juga terlihat bahwa penurunan CAI serapan karbon pada lahan gambut dangkal setelah titik puncak terjadi secara perlahan sehingga setelah umur 3,5 tahun, CAI pada tipe lahan tersebut lebih besar dibanding tipe lahan gambut dalam yang mengalami penurunan drastis setelah titik puncak kurva.

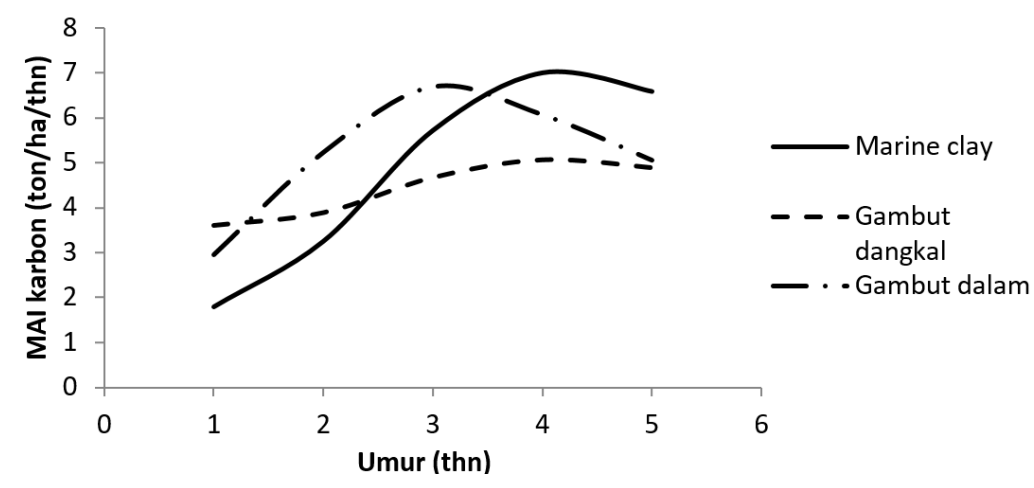

Gambar 2. Rata-rata serapan karbon krasikarpa pada tiga tipe lahan basah di Kabupaten OKI Sumatera Selatan

Figure 2. Mean annual increment of carbon sequestration on three wetland types in OKI District South Sumatera 


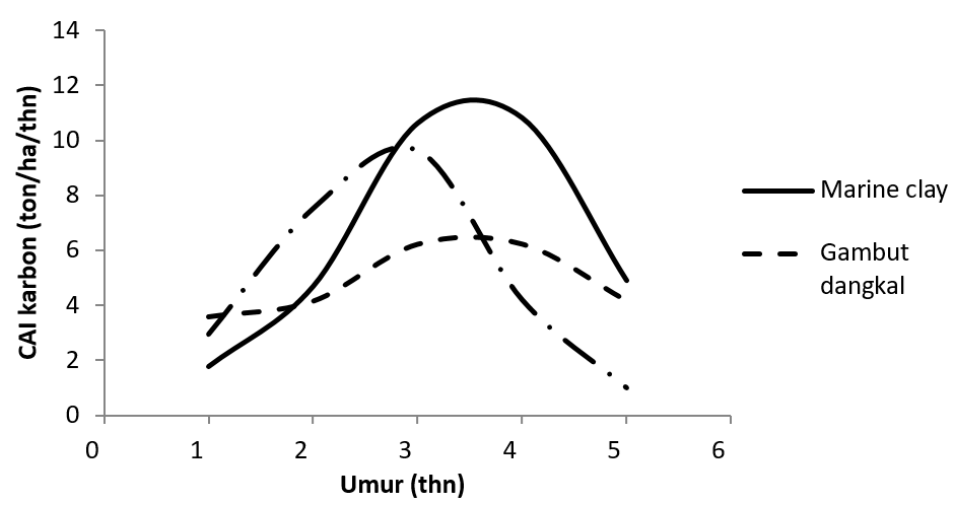

Gambar 3. Riap tahun berjalan serapan karbon pada tiga tipe lahan basah di Kabupaten OKI Sumatera Selatan

Figure 3. Current annual increment of carbon sequestration on three wetland types in OKI

\section{B. Pembahasan}

Besarnya serapan karbon melalui pertumbuhan dan akumulasi biomassa ditentukan oleh sifat pertumbuhan, kondisi lahan, serta kecocokan antara jenis yang dikembangkan dengan kondisi lahan pengembangannya (Mandal, Jha, Dutta, Thapa, \& Karmacharya, 2016). Krasikarpa merupakan salah satu jenis yang dipilih untuk ditanam pada lahan basah, baik pada tipe lahan endapan liat (marine clay) maupun lahan gambut, karena jenis ini tergolong jenis cepat tumbuh dan adaptif pada lahan basah. Sumadi \& Lestari (2013) melaporkan bahwa tegakan krasikarpa pada umur 6 tahun mencapai diameter $24,56 \mathrm{~cm}$ dan tinggi $18,80 \mathrm{~m}$ atau mempunyai riap diameter sebesar 4,09 cm/tahun dan riap tinggi sebesar 3,13 m/tahun. Hasil penelitian pertumbuhan krasikarpa di Provinsi Riau menunjukkan riap diameter yang sedikit lebih rendah yaitu sebesar $16,84 \mathrm{~cm}$ pada umur 5 tahun atau dengan riap 3,37 $\mathrm{cm} /$ tahun (Rochmayanto et al., 2013).

Beberapa penelitian terkait penyerapan karbon hutan tanaman pada lahan gambut telah dilakukan, khususnya pada lahan gambut di Pulau Sumatera. Namun umumnya penelitian dilakukan tanpa membedakan tipe lahan. Rochmayanto et al., (2013) melaporkan bahwa serapan karbon di lahan gambut di Riau pada hutan tanaman krasikarpa 39,51 ton/ha pada umur 5 tahun atau dengan riap 7,9 ton/ha/tahun. Berbeda dengan penelitian tersebut, penelitian ini menunjukkan adanya perbedaaan serapan karbon jika ditanam pada tipe lahan gambut yang berbeda. Serapan karbon terbesar terdapat pada tipe lahan endapan liat yaitu sebesar 34,82 ton/ha; selanjutnya pada tipe lahan gambut dangkal sebesar 28,05 ton/ha; dan pada tipe lahan gambut dalam sebesar 25,52 ton/ha. Besarnya potensi serapan karbon tersebut pada umumnya dicapai pada umur 6 tahun, sesuai dengan daur produksi yang ditetapkan.

Riap rata-rata (MAI) maksimum serapan karbon pada ketiga tipe lahan juga menunjukkan perbedaan. Pada tipe lahan endapan liat (marine clay), MAI maksimum dicapai pada umur 4,25 tahun yaitu sebesar 7 ton/ha/tahun sementara pada tipe lahan gambut dangkal (peat VI) dan gambut dalam (peat VII), masing-masing hanya mencapai 5,08 dan 5,89 ton/ha/tahun pada umur 4,25 dan 3,75 tahun.

Lahan endapan liat menyerap karbon lebih besar dibandingkan lahan gambut. Hal ini disebabkan salah satunya oleh unsur hara yang terdapat dan tersedia pada tipe lahan endapan liat lebih besar dibanding lahan gambut. Walaupun kandungan bahan organik banyak terdapat pada lahan gambut, unsur-unsur yang diperlukan oleh tanaman tidak tersedia secara langsung. Pada lahan gambut, kondisi anaerobik mengakibatkan proses pelapukan berlangsung dalam jangka waktu yang panjang dan sangat lambat. Proses pelapukan bahan organik juga berlangsung secara bertahap yang menghasilkan senyawa-senyawa yang tidak 
dapat diserap oleh tanaman. Selain itu, tipe lahan endapan liat merupakan akumulasi liat dalam periode waktu yang lama. Basack \& Purkayastha (2009) menyatakan bahwa lahan endapan liat mempunyai kapasitas pertukaran kation (KTK) yang tinggi.

Pertumbuhan tanaman di lahan gambut mengalami beberapa hambatan terkait dengan karakteristik material gambut tersebut. Lahan gambut memiliki sifat jenuh air, bereaksi masam, mengandung asam organik beracun, status hara yang rendah, dan secara mekanis mempunyai daya sanggah yang rendah (Subiksa, Hartatik, \& Agus, 2011). Daya sanggah lahan gambut yang rendah pada sistem perakaran terjadi karena bobot isi (bulk density) lahan gambut yang rendah terutama pada tingkat pelapukan fibrik dan hemik (Siahaan \& Sumadi, 2016). Rata-rata bobot isi lahan gambut di Sumatera Selatan sebesar 0,18 $\mathrm{gr} / \mathrm{cm}^{3}$ dengan kisaran antara 0,1-0,4 $\mathrm{grm} / \mathrm{cm}^{3}$ (Tiryana et al., 2016). Seiring dengan bertambahnya bobot biomassa tanaman hingga jumlah tertentu, sistem perakaran lahan gambut tidak mampu lagi menahan beban tersebut dan tanaman menjadi tumbang. Tumbangnya tanaman pada lahan gambut umumnya mulai terjadi pada umur 3-4 tahun setelah tanam dan pada umur 6 tahun, persentase tanaman yang tumbang umumnya telah melebihi $50 \%$.

Hasil penelitian ini dan beberapa penelitian lainnya menunjukkan bahwa cadangan karbon pada hutan tanaman yang dibangun di lahan gambut berkisar antara 25,52 hingga 39,51 ton/ha pada akhir daur. Jika dibandingkan dengan cadangan karbon biomassa di permukaan tanah pada hutan rawa gambut sekunder di Sumatera Selatan yang mencapai 97,3 ton/ha (Tiryana et al., 2016), hutan rawa gambut sekunder dan bekas tebangan di Pelalawan Riau (dengan kandungan karbon masing-masing sebesar 83,49; dan 126,0), maka pembangunan HTI dengan jenis krasikarpa pada hutan gambut sekunder atau bekas tebangan akan mengakibatkan penurunan cadangan karbon yang cukup signifikan. Oleh karena itu pembangunan hutan tanaman pada lahan rawa gambut harus dilakukan secara selektif pada tutupan lahan rendah karbon seperti semak belukar gambut atau padang rumput. Cadangan karbon pada semak belukar gambut lebih rendah dibanding hutan tanaman krasikarpa, misalnya pada semak belukar gambut bekas terbakar di Sepucuk, Kabupaten OKI sebesar 1,30 ton/ha (Prakosa, 2013). Hasil penelitian status lahan gambut di Sumatera menunjukkan bahwa $20 \%$ lahan gambut di Sumatera merupakan semak belukar tidak terkelola (Miettinen \& Liew, 2010) dan dari 1,28 juta lahan gambut di Sumatera Selatan, 0,61 juta ha ditutupi oleh semak belukar dan 0,17 juta ha berupa rumput-rumputan (Agus, 2013). Lahanlahan tersebut merupakan lahan-lahan potensial dijadikan sebagai areal pengembangan hutan tanaman.

\section{KESIMPULAN}

Hasil penelitian menunjukkan bahwa serapan karbon berbeda pada masingmasing tipe lahan basah. Serapan karbon terbesar terdapat pada tipe lahan endapan liat dengan serapan maksimum sebesar 34,82 ton C/ha, diikuti oleh tipe lahan gambut dangkal (peat VI) sebesar 28,05 ton $\mathrm{C} /$ ha dan tipe lahan gambut dalam (peat VII) sebesar 25,52 ton C/ha. Serapan maksimum ini umumnya telah tercapai pada umur 6 tahun sesuai dengan daur produksi tanaman. Riap serapan rata-rata maksimum terjadi pada umur 4,25 tahun pada tipe lahan endapan liat dan gambut dangkal sebesar 7 dan 5,08 ton $\mathrm{C} /$ ha/tahun, tetapi pada lahan gambut dalam terjadi lebih dulu, yaitu pada umur 3,75 tahun sebesar 5,89 ton $\mathrm{C} / \mathrm{ha} /$ tahun. Sebagai konsekuensi dari perbedaan-perbedaan tersebut, maka pengelolaan hutan tanaman krasikarpa harus disesuaikan dengan tipe lahan pengembangannya.

\section{DAFTAR PUSTAKA}

Agus, F. (2013). Konservasi dan Rehabilitasi Lahan Gambut untuk Penurunan Emisi Karbon: Aplikasi untuk Provinsi Sumatera Selatan. In D. Purwito, T. E. Komar, A. Subiakto, Kuntadi, Haryono, \& S. Suri (Eds.), Prosiding Workshop ITTO Project RED-SPD 009/09 Rev.2 
(F), Stakeholder Consultation The Application of Method and Technologies to Enhance the Restoration of PSF Ecosystem (pp. 1-18). Bogor: Pusat Penelitian dan Pengembangan Konservasi dan Rehabilitasi (P3KR).

Basack, S., \& Purkayastha, R. D. (2009). Engineering properties of marine clays from the eastern coast of India. Journal of Engineering and Technology Research, 1 (6), 109-114.

Devi, B., Bhardwaj, D. R., Panwar, P., Pal, S., Gupta, N. K., \& Thakur, C. L. (2013). Carbon allocation, sequestration and carbon dioxide mitigation under plantation forests of north western Himalaya, India. Annals of Forest Research, 56 (1), 123-135. Retrieved from

http://www.scopus.com/inward/record. url?eid=2-s2.0-

84876583141\&partnerID $=40 \& \mathrm{md} 5=50$ 4d15488091f159b400b38da1bd44f8

Krisnawati, H. (2010). Status Data Stok Karbon Dalam Biomas Hutan Di Indonesia. In N. Masripatin \& C. Wulandari (Eds.), REDD+ \& Forest Governance (pp. 23-43). Bogor: Pusat Penelitian dan Pengembangan Perubahan Iklim dan Kebijakan.

Mandal, R. A., Jha, P. K., Dutta, I. C., Thapa, U., \& Karmacharya, S. B. (2016). Carbon Sequestration in Tropical and Subtropical Plant Species in Collaborative and Community Forests of Nepal. Advances in Ecology, 2016.

Marchio, D. A., Savarese, M., Bovard, B., \& Mitsch, W. J. (2016). Carbon sequestration and sedimentation in mangrove swamps influenced by hydrogeomorphic conditions and urbanization in Southwest Florida. Forests, https://doi.org/10.3390/f7060116

Miettinen, J., \& Liew, S. C. (2010). Status of Peatland Degradation and Development in Sumatra and Kalimantan, 394-401. https://doi.org/10.1007/s13280-0100051-2

Mitsch, W. J., Bernal, B., Nahlik, A. M., Mander, Ü., Zhang, L., Anderson, C. J., ... Brix, H. (2013). Wetlands, carbon, and climate change. Landscape Ecology, 28(4), 583-597. https://doi.org/10.1007/s10980-0129758-8

Prakosa, D. (2013). Pengukuran Cadangan Karbon di Atas Permukaan Tanah pada Hutan Gambut Sekunder Bekas Terbakar. In D. Purwito, T. E. Komar, A. Subiakto, Kuntadi, Haryono, \& S. Suri (Eds.), Prosiding Workshop ITTO Project RED-SPD 009/09 Rev.2 (F), Stakeholder Consultation The Application of Method and Technologies to Enhance the Restoration of PSF Ecosystem. Bogor: Pusat Penelitian dan Pengembangan Konservasi dan Rehabilitasi (P3KR).

Rochmayanto, Y., Darusman, D., \& Rusolono, T. (2013). Hutan Rawa Gambut dan HTI PULP dalam BINGKAI REDD +. (K. L. Ginoga, G. Pari, \& A. N. Gintings, Eds.). Bogor: Forda press.

Sang, P. M., Lamb, D., Bonner, M., \& Schmidt, S. (2013). Carbon sequestration and soil fertility of tropical tree plantations and secondary forest established on degraded land. Plant and Soil, 362 (1-2), 187-200. https://doi.org/10.1007/s11104-012$1281-9$

Siahaan, H., \& Sumadi, A. (2016). Tabel Tegakan Hutan Tanaman Industri Lahan Basah di Kabupaten Ogan Komering Ilir Sumatera Selatan. (Harbagung \& M. Rahmat, Eds.). Palembang: Universitas Muhammadiyah Palembang.

Subiksa, I., Hartatik, W., \& Agus, F. (2011). Pengelolaan Lahan Gambut Secara Berkelanjutan. In N. L. Nurida, A. Mulyani, \& F. Agus (Eds.), Pengelolaan Lahan Gambut Berkelanjutan (pp. 7388). Bogor. 
Sumadi, A., \& Lestari, S. (2013). Pertumbuhan Acacia crassicarpa pada Lahan Rawa Gambut Bekas Terbakar (Studi kasus di HTI PT. SBA Wood Industry). In D. Purwito, T. E. Komar, A. Subiakto, Kuntadi, Haryono, \& S. Suri (Eds.), Prosiding Workshop ITTO Project RED-SPD 009/09 Rev.2 (F), Stakeholder Consultation The Application of Method and Technologies to Enhance the Restoration of PSF Ecosystem (pp. 147-152). Bogor: Pusat Penelitian dan Pengembangan Konservasi dan Rehabilitasi (P3KR).

Sumadi, A., Rahmat, M., \& Rahman, T. (2013). Penyerapan Karbon pada Hutan Tanaman Acacia crassicarpa di Lahan Gambut Terdegradasi PT. SBA WI. In D. Purwito, T. E. Komar, A. Subiakto, Kuntadi, Haryono, \& S. Suri (Eds.), Prosiding Workshop ITTO Project REDSPD 009/09 Rev.2 (F), Stakeholder Consultation The Application of Method and Technologies to Enhance the Restoration of PSF Ecosystem (pp. 137146). Bogor: Pusat Penelitian dan Pengembangan Konservasi dan Rehabilitasi (P3KR).

Tiryana, T., Rusolono, T., Siahaan, $H_{\text {., }}$ Kunarso, A., Sumantri, H., \& Haasler, B. (2016). Cadangan Karbon Hutan dan Keanekaragaman Flora Di Sumatera Selatan. Palembang: German International Cooperation (GIZ).

Victor, D. G., Zhou, D., Ahmed, E. H. M., Dadhich, P. K., Oliver, J., Rogner, H.-H., Yamaguchi, M. (2014). Introductory Chapter. In O. Edenhofer, R. PichsMadruga, Y. Sokona, E. Farahani, S. Kadner, K. Seyboth, J. C. Minx (Eds.), Climate Change 2014: Mitigation of Climate Change Contribution of Working Group III to The Fifth Assessment Report of The Intergovermental panel on Climate Change (pp. 113-143). Cambridge: Cambridge University Press.
Wahyudi, \& Pamoengkas, P. (2013). Model Pertumbuhan Diameter Tanaman Jabon. Bionatura-Jurnal IImu-IImu Hayati Dan Fisik, 15 (1), 49-53.

Wibowo, A. (2010). Measureable, Reportable dan Verifyable (MRV) untuk Emisi Gas Rumah Kaca dari Kegiatan Kehutanan. In N. Masripatin \& C. Wulandari (Eds.), REDD+ \& Forest Governance (pp. 321). Bogor: Pusat Penelitian dan Pengembangan Perubahan Iklim dan Kebijakan. 